\title{
IAMJ
}

INTERNATIONAL AYURVEDIC MEDICAL JOURNAL

\section{UNDERSTANDING OF COVID 19 THROUGH AYURVEDIC PERSPECTIVE}

\section{Puneet Bhardwaj $^{1}$, Punita Sharma², Chhaju Ram Yadav ${ }^{3}$, Darshna H. Pandya ${ }^{4}$}

${ }^{1}$ PG Scholar, Department of Roganidan Evum Vikriti Vigyan, IPGT \& RA, Gujarat Ayurved University, Jamnagar, Gujarat, India

${ }^{2}$ PG Scholar, PG Department of Sharira Kriya, National Institute of Ayurveda, Jaipur, Rajasthan, India

${ }^{3}$ Associate Professor \& HOD, P.G. Department of Sharira Kriya, National Institute of Ayurveda, Jaipur, Rajasthan - 302002, India

${ }^{4}$ Assistant Professor, Department of Roganidan Evum Vikriti Vigyan, IPGT \& RA, Gujarat Ayurved University, Jamnagar, Gujarat, India

Corresponding Author: puneetbhardwaj381@gmail.com

\section{https://doi.org/10.46607/iamj1 1 p5022021}

(Published online: January 2021)

Open Access

(C) International Ayurvedic Medical Journal, India 2021

Article Received: 11/12/2020 - Peer Reviewed: 15/01/2021 - Accepted for Publication: 02/01/2021

Check for updates

\section{ABSTRACT}

According to WHO, viral diseases continue to emerge and represent a serious issue to public health. Ayurveda has a holistic approach with the aim of preventive as well as its curative aspect. In current era, there is advent of new diseases with every bit of time. For example, from last two decades SARS, MERS and now COVID-19, type of communicable diseases with no standard treatment protocol and vaccination. Ayurvedic principles are valid in all these conditions because these has been tested over a long period of time by various Acharyas and compiled it in Samhitas. This article will illustrate the principles of Ayurveda and their use in current situation i.e. COVID-19.

Keyword: Ayurveda, Janapadodhvamsa, Communicable disease, COVID - 19.

\section{INTRODUCTION}

A long healthy life is wish of every being since antiquity. Ayurveda is the science of life with the aim of attaining health and curing diseases of ill. ${ }^{1}$ Mind, soul and body are the three basic pillars of life. ${ }^{2}$ The combination of these three is responsible for existence of life. Natural calamities of high magnitude such as floods, 
famine, cyclone or even diseases like Plague, Cholera, COVID - 19 etc. leads to effect on large scale population. Situation involving the destruction or death of a population spread over a small locality, a country, a part of world or even the entire world is termed as Janpadodhvamsa. ${ }^{3}$ In Ayurvedic classics there is a comprehensible and lucid description regarding Janpadodhvamsa is available. As far as Brihatrayee is concern, there is a separate chapter named Janapadodhvamsa Vimaniya is available in Charaka Samhita, in Sushruta Samhita word 'Maraka' is mentioned which is related to epidemiology. ${ }^{4}$ Astang Samgraha has defined it in Viruddha Vijananiya Adhyaya ${ }^{5}$ as well as in Astang Hridaya it named as Agantuja roga..$^{6}$ Acharya Vagbhatta mentioned treatment also. Acharya Bhela has explained with the name 'Rituvyapattijjanmara' in 'Janpadvibhaktiyam Adhyaya'. ${ }^{7}$ Even though every in-。 dividual has different physical constitution, food habits, suitability, strength, immunity etc. still there are some factors common to all and the contamination of those factors leads to simultaneous manifestation of diseases having the same set of symptoms leading to the destruction of countries.

\section{Material and Methods}

Present work has been done based on critical review of classical information, published research works, modern literature and research works conducted at various institutes. The possible correlation information and has been presented in systematic way.

\section{Derivation and definition 'Janpadodhvamsa'}

The word Janpadodhvamsa comprises of two words, 'Janpada'- living in the country \& 'Udhvamsa' or destruction. ${ }^{8}$ The situation that leads to destruction of community is called Janpadodhvamsa.

\section{Definition of Epidemiology}

It is the study of relationship among various factors and conditions in the agent, host and environment that determine the frequency of occurrence and distribution of an infectious process; a disease or a physiological state in a population. ${ }^{9}$

\section{The Epidemiological Triad}

Occurrence and manifestation of any disease, whether communicable or non-communicable, are determined by the interaction between agent, host and environment, which together constitute the epidemiological triad. ${ }^{10}$

\section{Root cause for Janpadodhvamsa 'Adharma',11}

- Deviation from stipulated behaviour meant for protection and well-being of both society and individual.

- As this chain of disobedience increases the rulers to his citizens, its intensity increases.

- Leading to disturbance in Rituchakra and vitiation of Jala, Vayu, Desha and Kala.

\section{Aetiology of Janpadodhvamsa}

There are three major root cause mentioned in Ayurveda which can be applied on all diseases. As following: ${ }^{12}$

\section{Asatmyendriyarthasamyoga}

- Mithyayogovyadhikaranam. ${ }^{13}$

Improper utilization of sensory as with their objects is prime among the factors for production of diseases.

\section{Prajnaparadha}

- Cause of Adharmacharana.

- Caused by increased Rajas and Tamas; greed and selfishness; jealousy and anger.

- Leads to disturbance in physical and mental peace of the community and people are susceptible to diseases.

(a) Dhibhramsa (lack of intellect or ignorance)

(b) Dhritibhramsa (lack of awareness)

(c) Smritibhramsa (loss of memory)

\section{Parinama or Kala}

The external environment can trigger the disease by unbalancing the body through extreme and unnatural variations in temperature, rainfall or wind which in turn leads to cause of Janpadodhvamsa.

Acharya Charaka further defined Niyata hetu \& Aniyata hetu, Sadharana Hetu \& Asadharana Hetu in context to Janpadodhvamsa which also much responsible for mass destruction of community. ${ }^{14}$

\section{(a) Niyata Hetu or Inevitable factors}

Niyata Hetu includes the harmful effects of Sun, Moon, Stars and Planets such as floods, cyclones, landslides, earthquakes, tsunami etc. Influence on these also results in altered taste, potency, Vipaka \& other qualities of drugs, which lead to development of various disease. 


\section{(b) Aniyata Hetu or Evitable factors}

Aniyata Hetu includes Prajnaparadha (terrorism, accidents etc), Shastra Prabhavaja (wars- nuclear weapons, missiles, bioweapons like Anthrax, possibly COVID-19 etc), Abhishangaja (effects of pathogens, evil forces \& unhygienic condition) and Abhishapaja (curse). All these factors influence the individuals as well as society leading to destruction of large population and even responsible for the disease-causing organisms.
Janapadodhwamsakara Bhava (Nature of the vitiated factors)

Kalam Swabhavatah. Vidhyad Dushpariharyatwad Gareeyastaramrthvit. ${ }^{15}$

By nature, air, water, land and season are indispensable in their progressive order. But one should know that from out of four factors, it is easier to correct the vitiations of air, water and land than season. Because seasons are the most indispensable factor that cannot be treated.

Table 1: Classical viz contemporary Disasters classification: Comparison

\begin{tabular}{|l|l|l|l|}
\hline Sr. No. & Bhava & Features & Present interpretation \\
\hline 01. & Vayu $^{16}$ & $\begin{array}{l}\text { Atiparushamtisheetamatyush- } \\
\text { namatiruksha. } \\
\text { Atipratihatparasparagatiatikundalinsikta- } \\
\text { panshu. } \\
\text { Dhoomopahata. }\end{array}$ & $\begin{array}{l}\text { Extreme temp. } \\
\text { Storm }\end{array}$ \\
Fog \\
\hline 02. & Jala $^{17}$ & $\begin{array}{l}\text { Kledabahulamupkrantajala. } \\
\text { Upksheenajaleshaya. }\end{array}$ & $\begin{array}{l}\text { Flood } \\
\text { Mass movement (wet) i.e. Landslide }\end{array}$ \\
\hline 03. & Desha & $\begin{array}{l}\text { Pratatolkapatnirghata. } \\
\text { Bhoomikampa. } \\
\text { Guhyakaacharitamivakranditashabda- } \\
\text { bahulam. } \\
\text { Dhumrapavana. }\end{array}$ & $\begin{array}{l}\text { Meteorites. } \\
\text { Earthquake } \\
\text { Volcanic activity } \\
\text { Drought }\end{array}$ \\
\hline 04. & Kala & $\begin{array}{l}\text { Yathartulingad Vipreetalingamatilingama } \\
\text { Heenalingama. }\end{array}$ & Wrong/ Over/ Less presentation of Season \\
\hline
\end{tabular}

Impact of Contaminated 'Vayu' and 'Jala' on health Although there is no direct description of above but in various Samhita some scattered references about diseases which shows the relevance of contaminated Vayu and Jala in the pathogenesis of such manifestations. Few are given below-

Table 2: Diseases produced due to impure Air \& Water

\begin{tabular}{|l|l|l|}
\hline Sr. No. & Diseases due to impure air $^{20}$ & Diseases due to impure water \\
\hline 01. & Cough $($ Kasa $)$ & Skin diseases (Twaka vikara) \\
\hline 02. & Dyspnoea (Swasa kashtata) & Anaemia (Pandu) \\
\hline 03. & Vomiting (Chhardi) & Worms (Krimi) \\
\hline 04. & Rhinitis (Pratishyaya) & Elephantiasis (Shleepada) \\
\hline 05. & Headache (Shirashoola) & Ascites (Udara Roga) \\
\hline 06. & Fever (Jvara) & Heart diseases (Hridaya Roga) \\
\hline 07. & Acute eye diseases (Tivra Akshi Vikara) & Piles (Arsha) \\
\hline
\end{tabular}

Virus and Bacteria according to Ayurveda Ayurveda has detailed explanation of Sukshma or invisible entities named as Jivanu [bacteria with DNA] or Vishanu [Virus with RNA].

Pathophysiology of COVID-19 in relation to Agni and $A m a$
Agni and Immunity are most important aspects for survival in this pandemic. According to Ayurveda 13 types of Agni in human body to digest, transform, discriminate or disintegrate, metabolize various substances entering our body through various pathways- oral, nasal, skin pores, anal, vaginal etc. 
Agni maintain healthy physiological functions with quality and quantity (optimal) of Ojas. Ojas is responsible for our immunity (physical and mental).

Ama means undigested or improperly digested food which is a result of Mandagni leads to Ojovyapat. At cellular level the Pilu Agni and Pithara Agni are weaken by Ama and the Vishanu of COVID-19 can easily assemble itself to take control of cell function without being destroyed by cellular Agni and Ojas.

\section{General Principles for Prevention and Control}

The WHO has listed the following five general principles to control the pollution. ${ }^{22}$

(a) Containment -Preventing the pollutants from escaping into air from source of production.

(b) Replacement - Changing the existing techniques to those producing less amount of pollutants.

(c) Dilution - Diluting the concentration of pollutants in the air to such a level that they can be removed by natural means, such as foliage.

(d) Legislation - Enacting suitable aimed at prevention of pollution.

(e) International action - The WHO has established two international pollution monitoring centres at Washington DC and London, three regional centres at Tokyo, Moscow and Nagpur and 20 Laboratories in different countries.

\section{Principle of Management}

(A) Importance of Panchkarma and Rasayana therapy $^{23}$

Although epidemics are matter of concern, but we need not to worry rather than planning for proper medication.

One can prevent itself in spite of contamination of all the factors; by taking medicines properly those collected before the onset of epidemics. ${ }^{24}$ Even effects of Rasayana (Immunomodulatory changes) and Panchkarma greatly depends upon following Sadvritta, Achara Rasayana, Vyayama etc.

\section{(B) Importance of Rasa Kalpa}

Ayurvedic Herbo Mineral compounds or Rasa Kalpa are result of advanced science in the ancient time. Many medicinal formulas like Bhasma or ashes of purified Gold, Copper, Mica, Zink, Lead, Mercury and gemstones like diamond, Rubies, Pearls, Corals are used in treating terminal illness like cancer and viral infections.

Besides that, many herbs and compounds show antiviral activity to destroy the viruses, also help to strengthen the Ojas and Agni to protect the cell form invasion of the viruses. These types of combinations may help to survive and came out with minimal complications.

\section{(C) Role of Psychological Impact}

As a part of prevention and management codes of conduct, chanting of Mantra etc. are useful to enhance the mental capacity of the individual and with secretion of positive neurotransmitters. It may help to increase immunity so that any subject might be able to recover from epidemic. Truthfulness, compassion for living beings, charity, sacrifices, prayers to the god, adoption of preventive measures, tranquillity etc. are good for the mental health. Discussion of religious scriptures, great sages and those who have self-control and constantly associated with religious and Satvika Purusha are also act as therapies which strengthen the Satva which is very useful in prevention in psychological traits. Specially deaths caused by depression during the epidemic/pandemic due to insecurity of loss of jobs, social isolation and money crisis etc. So, the processes related to strengthen the Satva may save the lives.

\section{(D) Importance of Codes \& Conducts (Sadvritta)}

Sadvritta is not only about mental faculties, but also rules related with public hygiene, food consumption, sexual intercourse \& exercise etc. leads to prevention of psychological, physical \& psychosomatic disorders. Sneezing, laughing without covering the mouth, itching the nostrils etc. are known as bad conducts. ${ }^{25}$ These bad habits increase the chances of communicable diseases.

(E) Purification of Vayu according to Ayurveda ${ }^{26}$ Fumigation [Dhoopan]: Laksha, Haridra, Ativisha, Haritaki, Musta, Ela, Somavalka, Kushtha and Priyangu are used in the form of fumes to purify air. Karpura, Devadaru, Chandana, Srivasa, Sarja, Agaru, Nimba, Somaraji, Gandhaka, Guggulu are to be used in Havana. Fumigation of all such herbs makes the air pure, generates more Oxygen as well as kills microbes and microbe containing aerosols from the environment. 
And in this way, it helps to maintain preventive and curative measures.

\section{(F) Purification of Jala according to Ayurveda}

Water which is purified by the rays of the sun \& moon called Antariksha Jala [purest form of water]. If kept in a good and clean container, it acts as strength promoter, rejuvenator, tridosahara $\&$ brain tonic. ${ }^{27}$

Boiling over fire, heating by exposing to sunrays, immersing heated iron balls, sand or stone into water are the method to purify contaminated water. Use of warm water is also mentioned in advisory issued by ministry of AYUSH.

Putting flower such as Naga, Champaka, Utapala, Patala etc. into water for some time, removes bad smell and imparts good smell. ${ }^{28}$

It's also advised to store in vessels made of gold, silver, copper, bronze, precious stones or in earthen pots and made fragrant by putting flower into it, should be used for drinking. ${ }^{29}$

Methods of clearing the turbidity - Use of Katala, Gomedaka, Bisgranthi, Saivalmula, Vastra, Mukta and $\operatorname{Mani}$ (gems). ${ }^{30}$

Bhasma of Dhava, Ashwakarna, Asana, Paribhadra, Patala, Nirgundi, Mokha, Amlatasa, Somavalka etc. is used to purify the water. ${ }^{30}$

(G)Bhoomi Shodhana (Purification of Land)

Cleaning, grazing of cows, sprinkling of water etc. maybe the practices for Land purification. Houses can be purified by wiping, washing and painting with white colour.

\section{DISCUSSION}

Time to time the entire universe faced pandemics. Firstly, it was recorded in 1720 i.e. Plague which killed masses of people across the world. Second pandemic in 1820 was Cholera in Asia that was started from Calcutta and spread throughout the Asia. The next pandemic in year 1920 by the name of Spanish flu was the one of most-deadliest pandemic for the humanity ever. And now, the whole world is crippling due to the highly spreading pandemic called Covid-19. In Ayurveda, natural calamities like epidemics and pandemic diseases are described under the term of Janpadodhwamsa. Further, COVID-19 infection may be correlated with Vata-
Kapha Sannipataja Jwara (a type of fever with severe complications and fatality). Acharya told that invasion of Bhuta leads to death of the people in mass number. In present era, Bhuta can be understand as Virus/ Bacteria. Unethical practices are the basic cause of an epidemic or pandemic which includes food habits and lifestyles improperly. Which further leads to disturbance of biological, physical, social and economic conditions. Air and water born infections; disease arises as seasonal hazards are the prime cause for the same. Frequent contact with affected person, physical relationship or using same things that used by affected person are the cause of spreading. In COVID-19, the physical and social contact, contaminated air ( $\mathrm{Vayu})$ with droplet infection and place means hotspot areas with cluster of infected persons (Desha) are main source of transmission of infection. This can be prevented by social distancing, fumigation (Dhupana) and sprinkling of medicated water (Parisheka) respectively. In COVID19 treatment, good immunity is important factor for arresting the disease, which can attain by regular administration of Rasayana therapy. Changes in season can be predicted and before starting of epidemics / pandemics adequate arrangements and planning can be done so that can minimize the morbidity. Early detection can help for rapid implementation of effective measures which reduce the risk of disastrous spread.

\section{CONCLUSION}

On the basis of above discussion, it is certified that immunity is the key factor while dealing with such epidemics or pandemics. Any physician is supposed to assess the immunity of any subject during fight against such deadliest health problems. It plays an important role in maintaining good health and prognosis of disease. The same theory applies on COVID-19 or any epidemic or pandemic condition. The prevention can be achieved by all good codes and conducts like proper food habits and lifestyles as well as Vyayma and rejuvenation therapy. People should be aware about their health and adopt good habits, which would help the most. Government should also implement these principles in National Health Policies to make the nation fit and fine. 


\section{REFERENCES}

1. Dr. Brahmanand Tripathi, Charaka Samhita, Chaukhambha Surbharati Varanasi, Edition 2012, Sutra sthana, chapter no. 30, Shloka 26, page no. 565

2. Dr. Brahmanand Tripathi, Charaka Samhita, Chaukhambha Surbharati Varanasi, Edition 2012, Sutra sthana, chapter no. 01, Shloka 46, page no. 17.

3. Kaviraj Gangadhara Rai, Charaka Samhita, jalpakalpataru teeka, Vimana Sthana, Chapter no. 03, Shloka $1-2$.

4. Kaviraj Ambikadutta Shastri, Sushruta Samhita, Chaukhambha Sanskrit Sansthan Varanasi, Edition 2014, Sutra Sthana, Chapter 06, Shloka 19, page no. 30.

5. Dr. K.H. Krishnamurthy, Astang Samgraha, Chaukhambha Orientalia Varanasi, 2015, Sutra Sthana, Chapter 09, Shloka 71-72, page 215-216.

6. Kaviraj Atridev Gupt, Astang Hridaya, Vidhyotini Hindi Teeka, Chaukhambha Prakashan Varanasi, edition 2015, Sutra Sthana, chapter 04, Shloka 31, page 48.

7. Dr. K.H. Krishnamurthy, Bhela Samhita, Chaukhambha Vishvabharati Varanasi, Edition 2008, Sutra Sthana, Chapter no. 13, Shloka no. 9, page no. 59

8. M. Monier- Williams, Edited \& Revised by Pandit Ishwar Chandra, Sanskrit - English Dictionary with special reference to cognate Indo- European languages, 2011, Parimal publication Delhi, Vol. 01, page 616.

9. MC Gupta, BK Mahajan, Textbook of Preventive and Social Medicine, Jaypee, Ed. 2003, Chapter 02, page 11.

10. MC Gupta, BK Mahajan, Textbook of Preventive and Social Medicine, Jaypee, Ed. 2003, Chapter 02, page 12.

11. Dr. Brahmanand Tripathi, Charaka Samhita, Chaukhambha Surbharati Varanasi, Edition 2012, Vimana sthana, chapter no. 03, Shloka 20, page no. 680.

12. Dr. Lakshmidhar Dwivedi, Dr. B K Dwivedi, Dr. Pradeep Kumar Goswami, Charaka Samhita, Chaukhambha Krishnadas Academy Varanasi, Edition 2017, Nidana Sthana, Chapter 01, shloka 03, page 641-642.

13. Dr. Brahmanand Tripathi, Charaka Samhita, Chaukhambha Surbharati Varanasi, Edition 2012, Sutra sthana, chapter no. 25, Shloka 40, page no. 454.

14. Dr. Brahmanand Tripathi, Charaka Samhita, Chaukhambha Surbharati Varanasi, Edition 2012, Vimana sthana, chapter no. 03, Shloka 23, page no. 680.

15. Dr. Brahmanand Tripathi, Charaka Samhita, Chaukhambha Surbharati Varanasi, Edition 2012, Vimana sthana, chapter no. 03, Shloka 10, page no. 678.

16. Dr. Brahmanand Tripathi, Charaka Samhita, Chaukhambha Surbharati Varanasi, Edition 2012, Vimana sthana, chapter no. 03, Shloka 6 (1), page no. 677.

17. Dr. Brahmanand Tripathi, Charaka Samhita, Chaukhambha Surbharati Varanasi, Edition 2012, Vimana sthana, chapter no. 03, Shloka 06 (2), page no. 677.

18. Dr. Brahmanand Tripathi, Charaka Samhita, Chaukhambha Surbharati Varanasi, Edition 2012, Vimana sthana, chapter no. 03, Shloka 06 (3), page no. 677.
19. Dr. Brahmanand Tripathi, Charaka Samhita, Chaukhambha Surbharati Varanasi, Edition 2012, Vimana sthana, chapter no. 03, Shloka 06 (4), page no. 677.

20. Kaviraj Ambikadutta Shastri, Sushruta Samhita, Chaukhambha Sanskrit Sansthan Varanasi, Edition 2014, Kalpa Sthana, Chapter 03, Shloka 16, page no. 40.

21. Kaviraj Ambikadutta Shastri, Sushruta Samhita, Chaukhambha Sanskrit Sansthan Varanasi, Edition 2014, Sutra Sthana, Chapter 45, Shloka 21, page no. 220.

22. WHO: Tech Rep Sr No 406, 1968.

23. Dr. Brahmanand Tripathi, Charaka Samhita, Chaukhambha Surbharati Varanasi, Edition 2012, Vimana sthana, chapter no. 03, Shloka 12-18, page no. 679.

24. Dr. Brahmanand Tripathi, Charaka Samhita, Chaukhambha Surbharati Varanasi, Edition 2012, Vimana sthana, chapter no. 03, Shloka 14, page no. 679.

25. Dr. Brahmanand Tripathi, Charaka Samhita, Chaukhambha Surbharati Varanasi, Edition 2012, Sutra sthana, chapter no. 08, Shloka 19, page no. 198-199.

26. Kaviraj Ambikadutta Shastri, Sushruta Samhita, Chaukhambha Sanskrit Sansthan Varanasi, Edition 2014, Kalpa Sthana, Chapter 03, Shloka 17, page no. 40.

27. Kaviraj Ambikadutta Shastri, Sushruta Samhita, Chaukhambha Sanskrit Sansthan Varanasi, Edition 2014, Sutra Sthana, Chapter 45, Shloka 25-26, page no. 220.

28. Kaviraj Ambikadutta Shastri, Sushruta Samhita, Chaukhambha Sanskrit Sansthan Varanasi, Edition 2014, Sutra Sthana, Chapter 45, Shloka 12, page no. 219.

29. Kaviraj Ambikadutta Shastri, Sushruta Samhita, Chaukhambha Sanskrit Sansthan Varanasi, Edition 2014, Sutra Sthana, Chapter 45, Shloka 13, page no. 219.

30. Kaviraj Ambikadutta Shastri, Sushruta Samhita, Chaukhambha Sanskrit Sansthan Varanasi, Edition 2014, Sutra Sthana, Chapter 45, Shloka 17, page no. 219.

31. Kaviraj Ambikadutta Shastri, Sushruta Samhita, Chaukhambha Sanskrit Sansthan Varanasi, Edition 2014, Kalpa Sthana, Chapter 03, Shloka 09, page no. 40.

\section{Source of Support: Nil \\ Conflict of Interest: None Declared}

How to cite this URL: Puneet Bhardwaj et al: Understanding of COVID 19 Through Ayurvedic Perspective. International Ayurvedic Medical Journal \{online\} 2021 \{cited January, 2021\} Available from: http://www.iamj.in/posts/images/upload/2727 2732.pdf 